УДК 517.946 .9

\title{
A method for solving a boundary value problem in a multilayered area
}

\author{
Elena Kobilskaya, Viktor Lyashenko
}

Elena Kobilskaya

Viktor Lyashenko

\author{
Candidate of Physical and Mathematical Sciences, Associate Professor of the \\ Department of Mathematics and Computer Science, \\ Kremenchuk Mykhailo Ostrohradsky National University, \\ 20 Pershotravneva str., Kremenchuk, Ukraine,39600 \\ e-mail: kobilskaya1983@gmail.com \\ https://orcid.org/0000-0002-4210-1534
}

\author{
Doctor of Technical Sciences, Professor; Head of the Department of \\ Mathematics and Computer Science, \\ Kremenchuk Mykhailo Ostrohradsky National University, \\ 20 Pershotravneva str., Kremenchuk, Ukraine,39600 \\ e-mail:_viklyash2903@gmail.com; \\ https://orcid.org/0000-0002-4538-631X
}

\begin{abstract}
A method of solving the boundary-value problems for heat conduction equation in a complex area - a multi-layered cylinder with internal heat sources in some layers and external ones in other layers, is proposed. A method of problem solution in conditions of uncertainty of one of the boundary condition at the layers interface with conductive heat exchange between the layers is reviewed. The principle of method is in the averaging of temperature distributions radially in the internal layers. A boundary condition of the impedance-type conjugation appears as a result of transformations at the layers interface. The analytical and numeric-analytical solutions of simplified problems have been obtained. The mathematical model of a thermal process in an electrical machine presented as a three-layer cylinder, where internal heat sources operate in one layer and heat is submitted to the other two by means of heat conduction, has been built as an example.
\end{abstract}

Ключові слова: electric machine, mathematical model, temperature field, multi-layered cylinder

\section{Метод розв'язання крайових задач в багатошарових областях}

\author{
О.Б. Кобильська, В.П. Ляшенко
}

\author{
Кобильська Олена \\ Борисівна
}

\author{
Ляшенко Віктор \\ Павлович
}

\begin{abstract}
кандидат фізико-математичних наук, дочент; професор кафедри інформатики і вищої математики, Кременчуцький національний університет ім. Михайла Остроградського, вул. Першотравнева, 20, м. Кременчук, 61046, Украӥна
\end{abstract}

доктор технічних наук, професор; завідувач кафедри інформатики і вищої математики,

Кременчуцький національний університет ім. Михайла Остроградського, вул. Периотравнева, 20, м. Кременчук, 61046, Украйна

Запропонований метод розв'язання крайових задач для рівняння теплопровідності у складній області багатошаровому циліндрі, де в одній частині шарів діють внутрішні джерела тепла, а у іншій - зовнішні. Розглянуто метод розв'язку задачі в умовах невизначеності однієї з граничних умов на межі шарів 3 кондуктивним теплообміном між шарами. Сутність методу полягає в усереднені температурних розподілів за радіусом у внутрішніх шарах. Процес усереднення температурного розподілу уздовж радіуса, якщо це дозволяє фізична модель задачі, знижує іiі розмірність, але у результаті перетворень з'являється на межі шарів гранична умова імпедансного типу. Шляхом послідовного усереднення за радіусом, використовуючи умову спряження на межі шарів визначається температурний розподіл в останньому шарі. Для визначення температурного розподілу в останьому шарі побудована кінцеворізницева схема Кранка-Ніколсон. Наступний крок визначення температурних розподілів у багатошаровому циліндрі полягає у зворотному розв'язанні задач від останнього шару до першого. Розв'язуючи задачу від останнього шару до першого на кожному шарі отримується матриця значень температур, що використовуємо для розв'язання задачі як граничну умову для наступного шару. Це дає можливість знайти температурний розподіл в усьому циліндрі. У якості прикладу побудована математична модель теплового процесу у електричній машині, яка представлена у вигляді тришарового циліндра, де в одному 3 шарів діють внутрішні джерела тепла, а до двох інших тепло передається теплопровідністю. Отримано аналітичний та чисельно - аналітичний розв'язок спрощених задач. Проведено чисельні розрахунки, знайдено розв'язок нелінійної задачі та побудовані графіки температурних розподілів. 
Kеушords: електрична машина, математична модель, температурне поле, багатошаровий ичиліндр

\title{
Метод решения краевых задач в многослойных областях
}

\author{
Е.Б. Кобыльская, В.П. Ляшенко
}

\section{Кобыльская \\ Елена Борисовна}

Ляшенко
Виктор Павлович

\begin{abstract}
кандидат физико-математических наук, доцент; профессор кафедры информатики и высшей математики, Кременчугский национальный университет им. Михаила Остроградского, ул. Первомайская, 20 39600, г. Кременчуг, Украина

доктор технических наук, профессор заведующий кафедрой информатики и высшей математики, Кременчугский начиональный университет им. Михаила Остроградского, ул. Первомайская, 20, г. Кременчук, 61046, Украина
\end{abstract}

\begin{abstract}
Предложен метод решения краевых задач для уравнения теплопроводности в сложной области - многослойном цилиндре, где в одной части слоев действуют внутренние источники тепла, а в другой - внешние. Рассмотрен метод решения задачи в условиях неопределенности одного из граничных условий на границе слоев с кондуктивным теплообменом между слоями. Сущность метода заключается в усреднении температурных распределений по радиусу во внутренних слоях. В результате преобразований на границе слоев появляется граничное условие сопряжения импедансного типа. В качестве примера построена математическая модель теплового процесса в электрической машине, которая представлена в виде трехслойного цилиндра, где в одном из слоев действуют внутренние источники тепла, а в двух других тепло передается теплопроводностью. Получено аналитическое и численно - аналитическое решение упрощенных задач. Проведены численные расчеты, найдено решение нелинейной задачи и построены графики температурных распределений. Предложеный метод решения особенно будет полезен при решении тепловых задач в сложных многослойных областях, например в электрических машинах или в валковых кристаллизаторах.
\end{abstract}

Ключевые слова: электрическая машина, математическая модель, температурное поле, многослойный цилиндр

\section{Introduction}

In the mathematical modelling problems of thermal processes a range of challenges related to nonlinear nature of the problems, complexity of investigation areas and boundary conditions at their interfaces, inhomogeneous medium limiting the investigation areas, as well as tridimensionality of the problems appears. For linear and some of the nonlinear problems with linear boundary conditions in canonical areas the analytical methods are applied (e.g. the Fourier method, the integral transformation method, the thermal potential method, the conformal representation method, the methods of problem linearization). These methods require of the researchers to simplify output problems of heat exchange to the level where problem solution becomes practically enforceable.

An important advantage of analytical solutions of heat exchange problems is a possibility to review their dependence on parameters in an explicit form. Analytical solutions help to sort out the determining criteria through all their diversity. It greatly facilitates the physical experiment set-up. The accurate analytical solutions often are used as standard solutions and serve as a test task for checking the adequacy of more complex nonlinear models.

In comparison with the above-mentioned analytical methods numerical methods give the opportunity to get a full quantitative description of heat exchange in the complex form constructions and use complex nonlinear mathematical models. Nonlinear mathematical models describe the investigated thermal processes more accurately in a wide range of geometrical and physical parameters [1-2].

Contemporary computer technologies allow using numerical methods to obtain mathematical prediction of thermal processes in quite complicated physical objects, particularly in modern electrical machines.

The electrical machines construction started to expand rapidly at the end of the XX century due to the development of small electrical machines for space, aircraft and electrical cars industries. A magnetic core and winding are active parts of any electrical machine. All the other parts are constructive ones which provide necessary toughness, durability, slewing capacity, and cooling. The range of operating temperatures of electrical machine plays an important role in their reliability.

The diversity of the types of electrical machines notwithstanding, they have a lot of common structural elements: a wire with low electrical resistance, an isolation material with high dielectric 
properties, magnetic conductors with anisotropic properties in orthogonal directions. That allows building mathematical models of electromagnetic and thermal processes in electrical machine. The method of temperature field investigation in a three-layer cylinder has been reviewed in the paper with the example of mathematical model of thermal process in a simplest electrical machine.

Determination of three-dimensional temperature distributions generated by electromagnetic field activity in electrical machines is an extremely complicated problem of mathematical modelling and mathematical physics [3-8]. Electromagnetic fields are described by the models containing the Maxwell's equations system, the equation of charge continuity and the Ohm's law [9-12].

$$
\begin{gathered}
\operatorname{rot} \vec{H}=\frac{4 \pi}{\kappa} \vec{J}+\frac{1}{\kappa} \frac{\partial \vec{E}}{\partial t}, \operatorname{rot} \vec{E}=\frac{1}{\kappa} \frac{\partial \vec{H}}{\partial t}, \\
\operatorname{div} \vec{E}=4 \pi \rho_{e}, \operatorname{div} \vec{H}=0, \frac{\partial \rho_{e}}{\partial t}+\operatorname{div} \vec{J}=0, \vec{J}=\sigma_{e} \vec{E} .
\end{gathered}
$$

Where $\vec{H}, \vec{E}, \vec{J}, \rho_{e}, \sigma_{e}$ are a magnetic field strength, an electric field strength, an electric current density, an electric charge density, an electrical conductivity. Presence of the fields and currents in an electrical machine stimulates an electrocaloric effect in the subareas where electrical current flows. So an energy equation must be added to the Maxwell's equation in the mathematical model in order to determine the temperature distributions in the windings and between them because the model will not be consistent without it. Furthermore, the electrical conductivity $\sigma_{e}$ of electrical machine windings depends on the temperature. To determine the internal energy in electrical machine the following form of the thermal conductivity equation is used

$$
\rho_{n} \frac{\partial e}{\partial t}=\operatorname{div}(\lambda(T) \operatorname{grad} T)+W(P, t, T),
$$

where $\lambda, \rho_{n}$ are a thermal conductivity coefficient and winding materials density, respectively, $e=\int_{\Omega} c_{\nu} d T$ is a specific internal energy, $c_{v}$ is a generalized thermal capacity of the environment, $W(P, t, T)$ is a density of heat sources in electrical machine windings. The displacement current $\frac{\partial \vec{E}}{\partial t}$ is neglected in many Maxwell's equations

$$
\operatorname{rot} \vec{H}=\frac{4 \pi}{\kappa} \vec{J}+\frac{1}{\kappa} \frac{\partial \vec{E}}{\partial t}
$$

in comparison with the conduction current $\vec{J}$ generated by the electrical current density. $\vec{H}$ is a magnetic field intensity in electrical machine windings, $\vec{E}$ is an electric field intensity, $\kappa$ is a speed of light. Such assumptions are appropriate because the displacement current $\frac{\partial \vec{E}}{\partial t}$ in electrical machines has much less influence on the temperature distribution than the conduction current $\vec{J}$. Also the Peltier heat which appears in the moving contacts is often neglected.

Accepting the abovementioned assumptions, the Maxwell's equations system can be written in the quasi-steady-state approximation in the area $\Omega_{t}$ in the following non-dimensional form

$$
\operatorname{rot} \vec{H}=4 \pi \sigma_{e} \vec{E}, \operatorname{rot} \vec{E}=-\frac{\partial \vec{H}}{\partial t}, \operatorname{div} \vec{H}=0, \vec{J}=\sigma_{e} \vec{E}=W(P, t) .
$$


Neglecting the displacement current $\frac{\partial \vec{E}}{\partial t}$ allows simplifying a mathematical model greatly by changing the equation system and turning it from the hyperbolic into parabolic. The model is significantly simplified by decreasing the number of boundary conditions.

Alternating electric current flowing through the electrical machine windings releases the energy in cases of both direct and backward current. Furthermore, electrical energy of alternating current causes the change of internal energy of conductors. Because of energy of alternating magnetic field and magnetic reversal, the coil cores are heated by the whirling currents. Electric and magnetic energy cause the rise of temperature of constructive elements. It is also called active energy, and the density of active heat sources can be determined by the formula

$$
W=J \times U \times R / Z, \quad R=\frac{\rho_{0} L(1+\beta \mathrm{T})}{S}, \quad Z=\sqrt{R^{2}+X_{L}^{2}},
$$

where $\mathrm{S}, \rho_{0}, \mathrm{X}_{L}, \mathrm{U}, \mathrm{Z}, \mathrm{R}$ are a wire section area, a specific resistance of winding wire, a winding inductance, a voltage in windings, an operating impedance, an active impedance. If the electrical machine power factor $\cos \varphi$ is known, the density of active heat sources is determined by the formula $W=\frac{J \times U \cos \varphi}{s}$.

Mathematical models that permit to investigate electromagnetic and thermal fields in electrical machine can be designated as the models of processes in a complex area. Therefore, the simplest case of the heat exchange process in electrical machine can be presented as the temperature field in a threelayered cylinder, where the internal heat sources operate in one layer (winding) and external heat sources operate in other two layers. The simpler case of temperature field in a two-layered cylinder has been reviewed in $[5,6]$.

\section{Purpose of the paper}

Purpose of the paper is to construct a mathematical model of temperature field in a multi-layered cylinder where internal heat sources operate in one part of the layers and external sources operate in another part, using the simplest electrical machine as an example. It is also necessary to develop a method for determining the temperature field in a complex multilayer area.

A schematic illustration of a three-layered cylinder is shown in Fig.1.

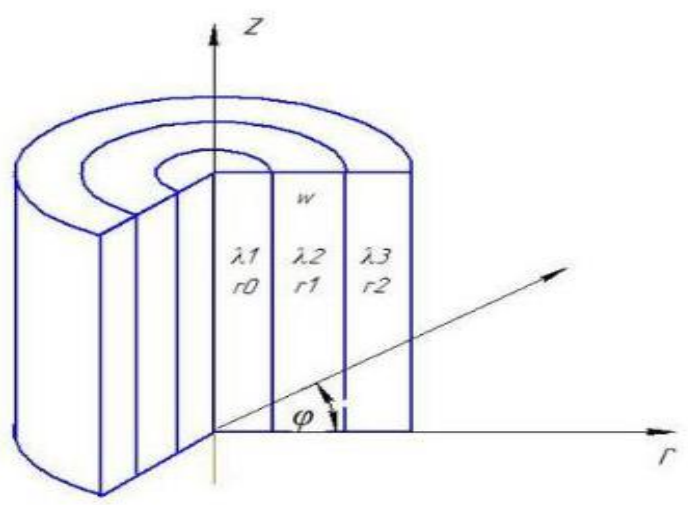

Figure 1. A three-layered cylinder with different thermal-physical characteristics of the layers.

\section{Study resources and results}

Let us consider the mathematical model of temperature field in a three-layered cylinder where internal heat sources work in one layer and heat is transferred by means of thermal conductivity to other two layers which have different thermal-physical properties. Internal heat sources constitute the Joule heat released while the electric current flows through one of the layers. Let us consider the temperature field of an electrical machine consisting of a two-layered rotor without heat sources and a stator with 
the windings of a copper wire or aluminum inserts where an electric current flow generates the Joule heat (see Fig. 1).

Determination of the temperature distribution $T(r, z, t)$ in a three-layered cylinder, where internal heat sources operate in the external layer and heat is transferred from the external layer to the internal ones by means of thermal conductivity, can be presented as the following boundary problem on conjunction in the area $\Omega \times t:\left\{0<r<r_{0}, 0<z<l, 0<t<t_{0}\right\}$

$$
\begin{gathered}
\lambda_{i} \frac{1}{r} \frac{\partial}{\partial r}\left(r \frac{\partial T_{i}}{\partial r}\right)+\lambda_{i} \frac{\partial^{2} T_{i}}{\partial z^{2}}-c_{i} \rho_{i} \frac{\partial T_{i}}{\partial t}=\left\{\begin{array}{c}
-\frac{I^{2} \rho_{0}(1+\beta T)}{S^{2}}, r_{1} \leq r<r_{2} \\
0, \quad 0<r<r_{0}, r_{0}<r<r_{1}, r>r_{2}
\end{array}\right. \\
T_{i}(r, z, 0)=T_{0}, \\
T_{i}(r, 0, t)=T_{0}, \quad T_{i}(r, l, t)=T_{0}, \\
\left.\frac{\partial T_{1}}{\partial r}\right|_{r=0}=0,\left.\quad \lambda_{3} \frac{\partial T_{3}}{\partial r}\right|_{r=r_{2}}=\left[-\alpha\left(T_{3}-T_{c}\right)-\varepsilon \sigma\left(T_{3}^{4}-T_{c}^{4}\right)\right], \\
\quad T\left(r_{i-0}, z, t\right)=T_{1}\left(r_{i+0}, z, t\right), \quad i=1 \ldots 3, \\
\left.\lambda_{i} \frac{\partial T_{i}}{\partial r}\right|_{r=r_{i}-0}=\left.\lambda_{i+1} \frac{\partial T_{i+1}}{\partial r}\right|_{r=r_{i+0}}, \quad i=1 \ldots 3,
\end{gathered}
$$

where $\lambda_{i}, c_{i}, \rho_{i}, i=1 \ldots 3, T_{c}$ are the respective thermal-physical characteristics and parameters of the parts of an electrical machine, the ambient temperature $\alpha, I, \rho_{0}, \varepsilon, \sigma, \beta$ are a heat transfer coefficient, a current strength, a resistivity of the windings wire, an emissivity factor, the StefanBoltzmann constant and a temperature coefficient of resistance, respectively. $S$ is a total section area of the wire in the stator windings, particularly $S_{3}=\pi\left(r_{2}^{2}-r_{1}^{2}\right)$ layer surface area $S_{3}$.

The problem as arranged in (1)-(6) is non-linear, so the analytical solution for it does not exist. Let us simplify the problem according to the following algorithm.

It is enough to know the homogenized temperature distribution in the third and second layers to investigate the temperature distribution in the inner cylinder. So to determine the transmission rate of heat flowing through the inner cylinder surface, let us multiply the equation (1) by $r d r$ and integrate over the layer thickness within the $r_{1}$ to $r_{2}$ limits

$$
\begin{gathered}
\left.\lambda_{3} r \frac{\partial T_{3}}{\partial r}\right|_{r=r_{1}} ^{r=r_{2}}+\lambda_{3} \frac{\partial^{2}}{\partial z^{2}} \int_{r_{1}}^{r_{2}} T_{3} r d r-c_{3} \rho_{3} \frac{\partial}{\partial t} \int_{r_{1}}^{r_{2}} T_{3} r d r=-\frac{I^{2} \rho_{0}}{S_{3}{ }^{2}} \int_{r_{1}}^{r_{2}}\left(1+\beta T_{3}\right) r d r, \\
\left.\lambda_{3} r \frac{\partial T_{3}}{\partial r}\right|_{r=r_{1}} ^{r=r_{2}}=-r_{2}\left(\alpha_{3}\left(T_{3}-T_{c}\right)+\varepsilon \sigma\left(T_{3}^{4}-T_{c}^{4}\right)\right)-\lambda_{3} r_{1} \frac{\partial T_{3}\left(r_{1}, z, t\right)}{\partial r} .
\end{gathered}
$$

After the transformations and using the ratio [13]

$$
u_{3}(z, t)=\frac{2}{S_{3}} \int_{\eta_{1}}^{r_{2}} T_{3}(r, z, t) r d r
$$

the equation (7) can be displayed in the form of 


$$
\begin{aligned}
\lambda_{3} r_{1} \frac{S_{3}}{2} \frac{\partial T_{3}\left(r_{1}, z, t\right)}{\partial r} & =\frac{\lambda_{3} S_{3}}{2} \frac{\partial^{2} u_{3}}{\partial z^{2}}-\frac{c_{3} \rho_{3} S_{3} \partial u_{3}}{2 \partial t}+\frac{I^{2} \rho_{0} \beta}{2 S_{3}} u_{3}+\frac{I^{2} \rho_{0}}{S_{3}^{2}}\left(\frac{r_{2}^{2}}{2}-\frac{r_{1}^{2}}{2}\right)- \\
-r_{2} & {\left[\alpha\left(u_{3}-T_{c}\right)+\varepsilon \sigma\left(u_{3}{ }^{4}-T_{c}^{4}\right)\right] . }
\end{aligned}
$$

The proportion (9) will be reviewed as a boundary condition of impedance type at the interface of the outer and inner cylinders. With $u(z, t) \approx T_{3}\left(r_{1}, z, t\right) \approx T_{2}\left(r_{1}, z, t\right)$ and taking into account the direction of the heat flow, the condition (9) could be written as

$$
\begin{aligned}
\lambda_{2} \frac{\partial T_{2}\left(r_{1}, z, t\right)}{\partial r}= & \frac{\lambda_{2}}{r_{1}} \frac{\partial^{2} T_{2}}{\partial z^{2}}-\frac{c_{3} \rho_{3} \lambda_{2}}{\lambda_{3} r_{1}} \frac{\partial T_{2}}{\partial t}+\frac{I^{2} \rho_{0} \beta \lambda_{2}}{\lambda_{3} r_{1} S_{3}{ }^{2}} T_{2}+\frac{I^{2} \rho_{0} \lambda_{2}\left(r_{2}^{2}-r_{1}^{2}\right)}{\lambda_{3} S_{3}{ }^{3} r_{1}}- \\
& -\frac{\lambda_{2} r_{2} 2}{r_{1} S_{3} \lambda_{3}}\left[\alpha\left(T_{2}-T_{c}\right)+\varepsilon \sigma\left(T_{2}{ }^{4}-T_{c}^{4}\right)\right] .
\end{aligned}
$$

After the determination of the boundary condition, the temperature distribution in the second layer of the cylinder can be reduced to the following problem with the condition that includes a tangent derivative alongside with a normal derivative by the direction of

$$
\begin{gathered}
\lambda_{2} \frac{1}{r} \frac{\partial}{\partial r}\left(r \frac{\partial T_{2}}{\partial r}\right)+\lambda_{2} \frac{\partial^{2} T_{2}}{\partial z^{2}}-c_{2} \rho_{2} \frac{\partial T_{2}}{\partial t}=0 \\
r_{0}<r<r_{1}, \quad 0<z<l, \quad t>0 \\
T_{2}(r, z, 0)=T_{0}, \\
T_{2}(r, 0, t)=T_{0}, \quad T_{2}(r, l, t)=T_{l}, \\
\lambda_{2} \frac{\partial T_{2}\left(r_{1}, z, t\right)}{\partial r}=\frac{\lambda_{2}}{r_{1}} \frac{\partial^{2} T_{2}}{\partial z^{2}}-\frac{c_{3} \rho_{3} \lambda_{2}}{\lambda_{3} r_{1}} \frac{\partial T_{2}}{\partial t}+\frac{I^{2} \rho_{0} \beta \lambda_{2}}{\lambda_{3} r_{1} S_{3}{ }^{2}} T_{2}+\frac{I^{2} \rho_{0} \lambda_{2}\left(r_{2}^{2}-r_{1}^{2}\right)}{\lambda_{3} S_{3}{ }^{3} r_{1}}- \\
-\frac{\lambda_{2} r_{2} 2}{r_{1} S_{3} \lambda_{3}}\left[\alpha\left(T_{2}-T_{c}\right)+\varepsilon \sigma\left(T_{2}{ }^{4}-T_{c}^{4}\right)\right], \\
\lambda_{2} \frac{T_{2}\left(r_{1+0}, z, t\right)}{\partial r}=\lambda_{1} \frac{\partial T_{1}\left(r_{1-0}, z, t\right)}{\partial r} .
\end{gathered}
$$

The second boundary condition in this problem arrangement (11)-(15) is indefinite. The method of determination of the temperature distribution in a multi-layered cylinder in the conditions of uncertainty is stepwise averaging of the temperature fields along the radius and the consequent determination of the temperature field in the first layer $0<r<r_{0}$. After finishing the averaging the backward process of determination of the temperature distribution in the inner layers starts $r_{0}<r<r_{1}$, $r_{1}<r<r_{2}, \cdots r_{N-1}<r<r_{N}$.

If it is possible to neglect the temperature distribution along the radius in the second layer of the cylinder, then, after averaging by analogy with (8) we get the boundary condition at the interface of the first and second cylinders 


$$
\begin{aligned}
& \lambda_{2} \frac{\partial T_{2}\left(r_{0}, z, t\right)}{\partial r}=\frac{\lambda_{2}}{r_{0}} \frac{\partial^{2} u_{2}}{\partial z^{2}}-\frac{c_{3} \rho_{3} \lambda_{2}}{\lambda_{3} r_{0}} \frac{\partial u_{2}}{\partial t}+\frac{I^{2} \rho_{0} \beta \lambda_{2}}{\lambda_{3} r_{0} S_{3}{ }^{2}} u_{2}+\frac{I^{2} \rho_{0} \lambda_{2}\left(r_{2}^{2}-r_{1}^{2}\right)}{\lambda_{3} S_{3}{ }^{3} r_{0}}- \\
& -\frac{\lambda_{2} r_{2} 2}{r_{0} S_{3} \lambda_{3}}\left[\alpha\left(u_{2}-T_{c}\right)+\varepsilon \sigma\left(u_{2}{ }^{4}-T_{c}^{4}\right)\right]+\frac{\lambda_{2}}{r_{0}} \frac{\partial^{2} u_{2}}{\partial z^{2}}-\frac{c_{2} \rho_{2}}{r_{0}} \frac{\partial u_{2}}{\partial t}=0 .
\end{aligned}
$$

In this way the temperature distribution in the inner cylinder (layer $S_{l}$ ) is determined from the solution of the following problem in the area $\Omega_{1} \times t=\left\{0<r<r_{0}, \quad 0<z<l, \quad t>0\right\}$

$$
\begin{aligned}
& \lambda_{1} \frac{1}{r} \frac{\partial}{\partial r}\left(r \frac{\partial T_{1}}{\partial r}\right)+\lambda_{1} \frac{\partial^{2} T_{1}}{\partial z^{2}}-c_{1} \rho_{1} \frac{\partial T_{1}}{\partial t}=0, \\
& T_{1}(r, z, 0)=T_{0}, \\
& T_{1}(r, 0, t)=T_{0}, \quad T_{1}(r, l, t)=T_{l}, \\
& \lambda_{1} \frac{\partial T_{1}\left(r_{0}, z, t\right)}{\partial r}=\frac{2 \lambda_{1}}{r_{0}} \frac{\partial^{2} u_{1}}{\partial z^{2}}-\left(\frac{\lambda_{1} c_{3} \rho_{3}}{\lambda_{3} r_{0}}+\frac{\lambda_{1} c_{2} \rho_{2}}{\lambda_{2} r_{0}}\right) \frac{\partial u_{1}}{\partial t}+\frac{I^{2} \rho_{0} \beta \lambda_{1}}{\lambda_{3} r_{0} S_{3}{ }^{2}} u_{1}+\frac{I^{2} \rho_{0} \lambda_{1}\left(r_{2}^{2}-r_{1}^{2}\right)}{\lambda_{3} S_{3}{ }^{3} r_{0}}- \\
& -\frac{\lambda_{1} r_{2} 2}{r_{0} S_{3} \lambda_{3}}\left[\alpha\left(u_{1}-T_{c}\right)+\varepsilon \sigma\left(u_{1}^{4}-T_{c}^{4}\right)\right]=0, \\
& \frac{\partial T_{1}(0, z, t)}{\partial r}=0, \\
& \mathrm{u}_{1}(z, t)=\frac{2}{S_{1}} \int_{0}^{r_{0}} T_{2}(r, z, t) r d r, \quad S_{1}=\pi r_{0}^{2}, \\
& \left.\lambda_{1} r \frac{\partial T_{1}}{\partial r}\right|_{r=0} ^{r=r_{0}}+\lambda_{1} \frac{\partial^{2}}{\partial z^{2}} \int_{0}^{r_{0}} T_{1} r d r-c_{1} \rho_{1} \frac{\partial}{\partial t} \int_{0}^{r_{0}} T_{1} r d r=0, \\
& \left.\lambda_{1} r \frac{\partial T_{1}}{\partial r}\right|_{r=0} ^{r=r_{0}}=2 \lambda_{1} \frac{\partial^{2} u_{1}}{\partial z^{2}}-\left(\frac{\lambda_{1} c_{3} \rho_{3}}{\lambda_{3}}+\frac{\lambda_{1} c_{2} \rho_{2}}{\lambda_{2}}\right) \frac{\partial u_{1}}{\partial t}+\frac{I^{2} \rho_{0} \beta \lambda_{1}}{\lambda_{3} S_{3}{ }^{2}} u_{1}+\frac{I^{2} \rho_{0} \lambda_{1}\left(r_{2}^{2}-r_{1}^{2}\right)}{\lambda_{3} S_{3}{ }^{3}}-\frac{\lambda_{1} r_{2} 2}{S_{3} \lambda_{3}}\left[\alpha\left(u_{1}-T_{c}\right)+\varepsilon \sigma\left(u_{1}^{4}-T_{c}^{4}\right)\right] .
\end{aligned}
$$

By using (24) in (23) and taking into account (22) we get

$$
\begin{aligned}
& \frac{\partial^{2} u_{1}}{\partial z^{2}}-\left(\frac{c_{3} \rho_{3}}{3 \lambda_{3}}+\frac{c_{2} \rho_{2}}{3 \lambda_{2}}+\frac{c_{1} \rho_{1}}{3 \lambda_{1}}\right) \frac{\partial u_{1}}{\partial t}+\left(\frac{I^{2} \rho_{0} \beta}{3 \lambda_{3} S_{3}{ }^{2}}-\frac{r_{2} 2 \alpha}{3 S_{3} \lambda_{3}}\right) u_{1}+\frac{I^{2} \rho_{0}\left(r_{2}^{2}-r_{1}^{2}\right)}{3 \lambda_{3} S_{3}{ }^{3}}+ \\
& +\left(\frac{r_{2} 2 \alpha}{3 S_{3} \lambda_{3}} T_{c}+\frac{r_{2} 2 \varepsilon \sigma T_{c}^{4}}{3 S_{3} \lambda_{3}}\right)-\frac{r_{2} 2 \varepsilon \sigma}{3 S_{3} \lambda_{3}} u_{1}{ }^{4}=0
\end{aligned}
$$

and come to the following boundary problem for a differential equation of the second order

$$
\begin{gathered}
\frac{\partial^{2} v}{\partial z^{2}}-a^{2} \frac{\partial v}{\partial t}+A v+C v^{4}=B, \quad 0<z<l, \quad t>0 \\
v(z, 0)=T_{0}
\end{gathered}
$$




$$
v(0, t)=T_{0}, \quad v(l, t)=T_{l},
$$

where

$$
\begin{aligned}
& A=\left(\frac{I^{2} \rho_{0} \beta}{3 \lambda_{3} S_{3}{ }^{2}}-\frac{r_{2} 2 \alpha}{3 S_{3} \lambda_{3}}\right), \quad a^{2}=\left(\frac{c_{3} \rho_{3}}{3 \lambda_{3}}+\frac{c_{2} \rho_{2}}{3 \lambda_{2}}+\frac{c_{1} \rho_{1}}{3 \lambda_{1}}\right), \quad C=-\frac{r_{2} 2 \varepsilon \sigma}{3 S_{3} \lambda_{3}}, \\
& B=-\left(\frac{I^{2} \rho_{0}\left(r_{2}^{2}-r_{1}^{2}\right)}{3 \lambda_{3} S_{3}{ }^{3}}+\frac{r_{2} 2 \alpha}{3 S_{3} \lambda_{3}} T_{c}+\frac{r_{2} 2 \varepsilon \sigma T_{c}^{4}}{3 S_{3} \lambda_{3}}\right) .
\end{aligned}
$$

Supposing that $\varepsilon=0$, the problem (26)-(28) can be solved by analytical means.

After replacing the variables

$$
v=e^{\mu z+\lambda t} \mathrm{u}, \quad \mu=0 \quad \lambda=\frac{A}{a^{2}}, \quad f(\mathrm{z}, \mathrm{t})=\mathrm{Be}^{-\lambda t},
$$

the equation (26) can be reduced to

$$
u_{t}=a^{2} u_{z z}+f(\mathrm{z}, t), \forall t>0, \quad 0<z<l
$$

with the nonhomogeneous boundary and initial conditions

$$
\begin{gathered}
u(z, 0)=\varphi(z)=\mathrm{T}_{0} e^{-\mu z}, \\
u(0, t)=\gamma_{1}(t)=\mathrm{T}_{0} e^{-\lambda t}, \quad u(l, t)=\gamma_{2}(t)=\mathrm{T}_{l} e^{-\mu l-\lambda t} .
\end{gathered}
$$

We seek the solution of the problem (29)-(31) as a sum of two functions

$$
u(z, t)=v(z, t)+w(z, t),
$$

where $v(z, t)$ is a new required function and $w(z, t)$ is an arbitrary function satisfying the nonhomogeneous boundary conditions

$$
w(\mathrm{z}, \mathrm{t})=\frac{z}{l}\left[\gamma_{2}(\mathrm{t})-\gamma_{1}(\mathrm{t})\right]+\gamma_{1}(\mathrm{t})
$$

The function $v(z, t)$ should satisfy the nonhomogeneous equation

$$
v_{t}-a^{2} v_{z z}=\bar{f}(\mathrm{z}, t)
$$

where

$$
\bar{f}(z, t)=f(z, t)-w_{t}-a^{2} w_{z z}
$$

and the additional initial and boundary conditions are

$$
\begin{aligned}
& v(\mathrm{z}, 0)=\varphi(\mathrm{z})-w(\mathrm{z}, 0), \\
& v(0, t)=\gamma_{1}(t)-w(0, t), \\
& v(l, t)=\gamma_{2}(t)-w(l, t) .
\end{aligned}
$$

After inserting (33) into (35) the conditions become nonhomogeneous and the problem (34)-(35) is reduced to 


$$
\begin{gathered}
u_{t}=a^{2} u_{z z}+f(\mathrm{z}, t), t>0, \quad 0<z<l \\
u(z, 0)=0, \\
u(0, t)=u(l, t)=0 .
\end{gathered}
$$

The solution of this problem has a form

$$
\begin{aligned}
& u(\mathrm{z}, t)=\int_{0}^{t} \int_{0}^{l}\left[\frac{2}{l} \sum_{n=1}^{\infty} e^{-\frac{n^{2} \pi^{2}}{l^{2}} a^{2}(t-\tau)} \sin \frac{n \pi}{l} z \sin \frac{n \pi}{l} \xi\right] f(\xi, \tau) d \xi d \tau= \\
& =\int_{0}^{t} \int_{0}^{l} G(z, \xi, t-\tau) f(\xi, \tau) d \xi d \tau .
\end{aligned}
$$

Therefore the problem (26)-(28) of determining the temperature distribution in the inner cylinder is completely solved. Then we build the finite-difference scheme of Crank-Nicolson [1-2]. In the area $\bar{\Omega} \times t \quad\{0 \leq z \leq l, t>0\}$ we apply the uniform grid by the length (coordinate $z$ ) of the cylinder $\bar{\omega}_{h}=\left\{z_{m}=m h, \quad m=0,1 \ldots M\right\}$; the time grid (coordinate $\left.t\right) \bar{\omega}_{\Delta t}=\left\{t_{j}=j \Delta t, j=0,1 \ldots j_{0}\right\}$ with the intervals: $h=l / M, \Delta t=t_{0} / j_{0}$.

The problem solution in the area $\Omega$ is sought as a solution of a system of nonlinear algebraic equations for the grid function $u_{z_{m}, t_{j}}$ marked as $u_{i}^{j}$.

$$
a^{2} \frac{u_{i}^{j+1}-u_{i}^{j}}{\Delta t}=\frac{u_{i-1}^{j+1}-2 u_{i}^{j+1}+u_{i+1}^{j+1}+u_{i-1}^{j}-2 u_{i}^{j}+u_{i+1}^{j}}{2 h^{2}}+A u_{i}^{j+1}+C\left(u_{i}^{j+1}\right)^{4}-B
$$

Let us review and solve the linearized problem. The obtained temperature values matrix is used for the solution of the problem (13)-(16) as a boundary condition.

For this purpose the finite-difference scheme of Douglas-Gann is built for by the alternating direction method [1-4] in the area $\bar{\Omega} \times t\left\{0 \leq r \leq r_{0}, 0 \leq z \leq l, t>0\right\}$ with the intervals $h_{1}=r_{0} / N, \quad h_{2}=l / M, \Delta t=t_{0} / j_{0}$ that has the form

$$
\begin{aligned}
& \frac{u_{n, m}^{j+1 / 2}-u_{n, m}^{j}}{\Delta t / 2}=\frac{\lambda_{2}}{r c_{2} \rho_{2}} \frac{u_{n+1, m}^{j+1 / 2}-u_{n, m}^{j+1 / 2}}{2 h_{1}}+\frac{\lambda_{2}}{c_{2} \rho_{2}} \frac{u_{n-1, m}^{j+1 / 2}-2 u_{n, m}^{j+1 / 2}+u_{n+1, m}^{j+1 / 2}}{h_{1}^{2}}+ \\
& +\frac{\lambda_{2}}{c_{2} \rho_{2}} \frac{u_{n, m-1}^{j}-2 u_{n, m}^{j}+u_{n, m+1}^{j}}{h_{2}^{2}} \\
& \frac{u_{n, m}^{j+1}-u_{n, m}^{j+1 / 2}}{\Delta t / 2}=\frac{\lambda_{2}}{r c_{2} \rho_{2}} \frac{u_{n+1, m}^{j+1 / 2}-u_{n, m}^{j+1 / 2}}{2 h_{1}}+\frac{\lambda_{2}}{c_{2} \rho_{2}} \frac{u_{n-1, m}^{j+1 / 2}-2 u_{n, m}^{j+1 / 2}+u_{n+1, m}^{j+1 / 2}}{h_{1}^{2}}+ \\
& +\frac{\lambda_{2}}{c_{2} \rho_{2}} \frac{u_{n, m-1}^{j+1}-2 u_{n, m}^{j+1}+u_{n, m+1}^{j+1}}{h_{2}^{2}}
\end{aligned}
$$

at the boundaries of the area

$$
\frac{-u_{2, m}^{j+1}+4 u_{1, m}^{j+1}-3 u_{0, m}^{j+1}}{2 h_{1}}=0, \quad n=0
$$

for $n=N$ we substitute the value of the temperature distribution matrix at the boundary of an outer cylinder. 
Fig. 2 shows the solution of the problem (34)-(35), that is the distribution of temperature in the inner layer of the cylinder along the coordinate $\mathrm{z}$.

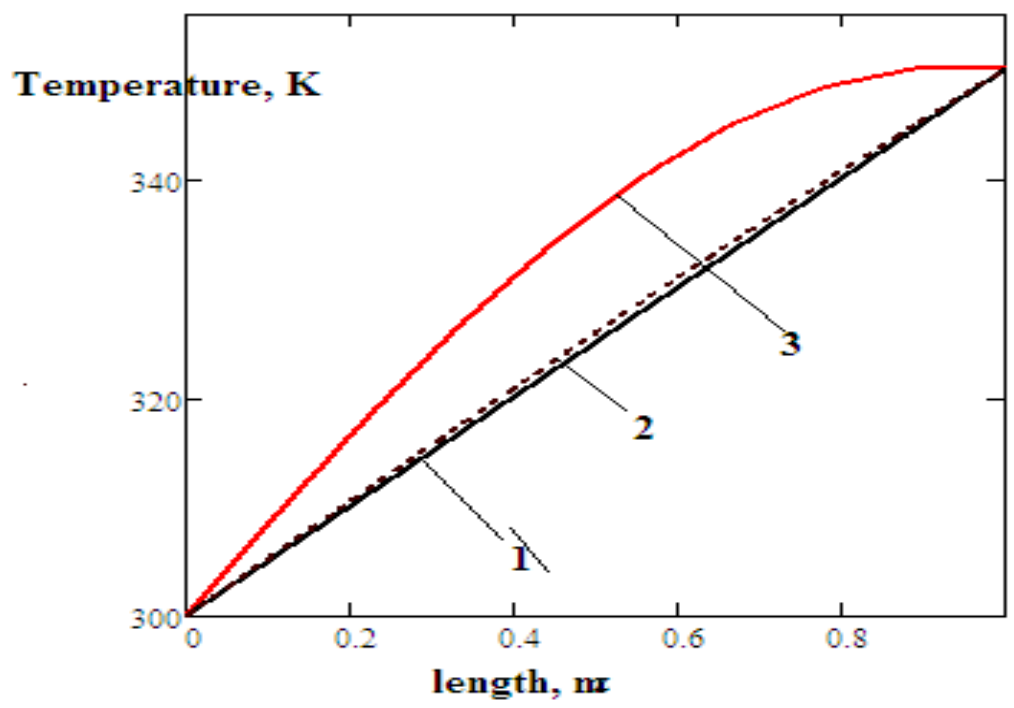

Figure 2. Solutions of the problem (34)-(35): curve 1- with $\alpha=1$, curve 2- $\alpha=10$, curve 3- $\alpha=100 \frac{m^{2}}{K}$

\section{Conclusions}

The general mathematical model of heat conduction in a complex multi-layered area has been developed in the paper. The method of solving the boundary problems for the heat conductivity equation in a complex area - a multi-layered cylinder with internal heat sources in some layers and external sources in other layers in the conditions of uncertainty of one of the boundary conditions at the layers interface and with conductive heat exchange between the layers is proposed. The principle of method is averaging the temperature distributions by the radius in the internal layers if the boundary condition by the radius in one of the layers is not determined. Averaging the temperature distribution along the radius decreases its dimensionality if it is allowed by the physical model of the problem, but as a result of the transformations, the boundary condition of impedance type appears at the interface of the layers. The temperature distribution in the last layer is determined by the stepwise averaging by the radius and using the conjunction condition at the interface of the layers. The next step of determining the temperature distributions in the multi-layered cylinder is the backward problem solution, from the last layer to the first. The analytical solution of the simplified problem for the three-layered cylinder where internal heat sources operate in one layer and heat is transferred to other two layers by means of heat conductivity is obtained. The numerical experiments have been conducted and the approximate solution of the nonlinear problem has been obtained. The temperature distributions are presented as the graphs.

\section{REFERENCES}

1. A.A. Samarsky, P.N. Vabishchevich, Computational Heat Transfer. Moscow: Editorial URSS, 2003, 785 p. [in Russian]. https://www.elibrary.ru/item.asp?id=19459203

2. R.D. Richtmyer, Difference Methods for Initial Value Problems. New York: Intercience, $1957,405 \mathrm{p}$.

https://epubs.siam.org/doi/abs/10.1137/1010073

3. V. Lyashenko and E. Kobilskaya, "Contact of boundary-value problems and nonlocal problems in mathematical models of heat transfer," in AMiTaNS'15, AIP Conf. Proc. Vol. 1684, edited by M.D. Todorov (American Institute of Physics, Melville, NY, 2014), paper 080009, 10p. https://aip.scitation.org/doi/abs/10.1063/1.4934320 
4. P. Slesarenko, O.P. Demyanchenko, V. P. Lyashenko and E. B. Kobilskaya "Numericalanalytical method in mathematical models of high-temperature processes". Visnyk of Kherson National Technical University, 3(54), pp. 467-471, 2015. [in Ukrainian]

http://www.irbis-nbuv.gov.ua/cgi-

bin/irbis nbuv/cgiirbis 64.exe?I21DBN=LINK\&P21DBN=UJRN\&Z21ID $=\& S 21 R E F=10 \&$

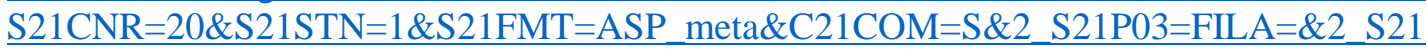
STR=Vkhdtu_2015_3_90

5. V. P. Lyashenko, N.G. Kirilaha "Mathematical model of induction heat of a relative frame skew field". Visnyk of Zaporizhzhya National University, 3, pp. 64-69, 2002. [in Ukrainian] https://web.znu.edu.ua/herald/issues/2002/2002-mf-bio-3.pdf

6. V. P. Lyashenko , T. A. Hryhorova, " Investigation of the temperature field of a two-layer cylinder with different thermophysical characteristics" Bulletin of V.N. Karazin Kharkiv National University, series "Mathematical modeling. Information technology. Automated control systems», Vol. 890, pp.47-52, 2010 [in Ukrainian] http://nbuv.gov.ua/UJRN/VKhIMAM_2010_890_13_8

7. O.A. Troitsky, V.I. Stashenko, V.G. Ryzhkov, V.P. Lyashenko, and E.B. Kobilskaya "Electroplastic drawing and new technologies for creating lightweight wires". Problems of Atomic Science and Technology, 4, pp.111-117, 2011.

https://docplayer.ru/44685115-Novi-tehnologiyi-v-mashinobuduvanni.html

8. V. Lyashenko and T. Hryhorova, "Generalized Mathematical Model of Thermal Diffusion in Powder Metallurgy," in AMiTaNS'14, AIP Conf. Proc. Vol. 1629, edited by M.D. Todorov (American Institute of Physics, Melville, NY, 2014), pp. 85-93. https://aip.scitation.org/doi/abs/10.1063/1.4902262

9. Richard P. Feynman, Robert B. Leighton, and Matthew Sands, The Feynman lectures on physics, Vol. II: Mainly Electromagnetism and Matter. New York: New millennium edition, 2010, pp. 324-410.

https://www.feynmanlectures.caltech.edu/II_toc.html

10. M. P. Galanin and Yu. V. Popov, Quasistationary electromagnetic fields in inhomogeneous media. Moscow: Nauka, 1995, 320 p. [in Russian].

https://www.elibrary.ru/item.asp?id=23951992

11. E. Tamm, Fundamentals of the Theory of Electricity. Moscow: Fizmatlit, 2003, 616 p. [in Russian].

http://www.samomudr.ru/d/Tamm\%20I.E.\%20 Osnovy\%20teorii\%20Elektrichestva 616str 2003g.pdf

12. L. D. Landau, E. M. Lifshitz, Electrodynamics of Continuous Media. Moscow: Nauka, 1982, 624 p. [in Russian].

https://radfiz.org.ua/files/k2/s3/TeopMex/Landau,Lifshic/Landay_VIII.pdf

13. A.V. Lykov, Theory of Heat Conductivity. Moscow: Gostekhizdat, 1967, pp. 31-32. [in Russian].

https://techliter.ru/load/uchebniki_posobya_lekcii/termodinamika_teplotekhnika/teorija_tepl oprovodnosti lykov a v/68-1-0-166

\section{ЛІТЕРАТУРА}

1. Самарский А.А., Вабищевич П.Н. Вычислительная теплопередача. Москва: Едиториал УРCC, 2003. $784 \mathrm{c}$.

https://www.elibrary.ru/item.asp?id=19459203

R.D. Richtmyer, Difference Methods for Initial Value Problems. New York: Intercience, 1957, 405 p. https://epubs.siam.org/doi/abs/10.1137/1010073

2. Lyashenko V., Kobilskaya E. Contact of boundary-value problems and nonlocal problems in mathematical models of heat transfer. Application of Mathematics in Technical and Natural Sciences: AIP Conf. Proc., June 28-July 3, 2015. American Institute of Physics, Melville, NY, 2015. P.080009-1 - 080009-10.

https://aip.scitation.org/doi/abs/10.1063/1.4934320 
3. Слесаренко А. П., Дем'янченко О. П., Ляшенко В. П., Кобильська О. Б. Чисельноаналітичний метод у математичних моделях високотемпературних процесів. Вісник Херсонського начіонального технічного університету. 2015. Вып. 3(54). С. 467-471. http://www.irbis-nbuv.gov.ua/cgi-

bin/irbis nbuv/cgiirbis 64.exe?I21DBN=LINK\&P21DBN=UJRN\&Z21ID=\&S21REF=10\&

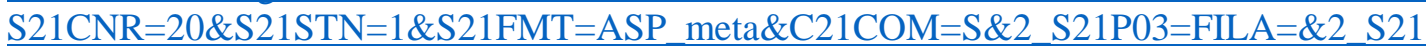
STR=Vkhdtu_2015_3_90

4. Ляшенко В.П., Кирилаха Н.Г. Математична модель індукційного нагріву рухомого тіла. Вісник Запорізького державного університету. 2002. № 3. С.64-69. https://web.znu.edu.ua/herald/issues/2002/2002-mf-bio-3.pdf

5. Ляшенко В. П., Григорова Т. А.Дослідження температурного поля двошарового циліндра 3 різними теплофізичними характеристиками. Вісник Харківського начіонального університету ім. В.Н. Каразіна серія «Математичне моделювання. Інформаційні технології. Автоматизовані системи управління» 2010. № 890, Вип. 13. C. $47-52$. http://nbuv.gov.ua/UJRN/VKhIMAM_2010_890_13_8

6. Кобильська О. Б., Троицкий О.А., Сташенко В.И., Рыжков В.Г., Ляшенко В.П. Электропластическое волочение и новые технологии создания облегченных проводов. Журнал «Вопросы атомной науки и техники». 2011. Вип. 4/2011. С. 111 - 117 https://docplayer.ru/44685115-Novi-tehnologiyi-v-mashinobuduvanni.html

7. Lyashenko V., Hryhorova T. Generalized Mathematical Model of Thermal Diffusion in Powder Metallurgy. Application of Mathematics in Technical and Natural Sciences: AIP Conf. Proc., June 26-July 1, 2014. American Institute of Physics, Melville, NY, 2014. P. 8593. https://aip.scitation.org/doi/abs/10.1063/1.4902262

8. Richard P. Feynman, Robert B. Leighton, and Matthew Sands, The Feynman lectures on physics, Vol. II: Mainly Electromagnetism and Matter. New York: New millennium edition, 2010, pp. 324-410.

https://www.feynmanlectures.caltech.edu/II_toc.html

9. Галанин М.П., Попов Ю.П. Квазистационарные электромагнитные поля в неоднородных средах: Математическое моделирование. Москва: Физматлит, 1995. $320 \mathrm{c}$.

https://www.elibrary.ru/item.asp?id=23951992

10. Тамм И.Е. Основы теории электричества. Москва: Физматлит, 2003. 616 с. http://www.samomudr.ru/d/Tamm\%20I.E.\%20_Osnovy\%20teorii\%20Elektrichestva_616str 2003g.pdf

11. Ландау Л. Д., Лифшиц Е. М. Электродинамика сплошных сред. Москва:Наука,1982. $624 \mathrm{c}$.

https://radfiz.org.ua/files/k2/s3/TeopMex/Landau,Lifshic/Landay_VIII.pdf

12. Лыков А.В. Теория теплопроводности. Москва: Гостехиздат, 1952. 392 с.

https://techliter.ru/load/uchebniki_posobya_lekcii/termodinamika_teplotekhnika/teorija_tepl oprovodnosti lykov a v/68-1-0-166 